\title{
CLINICAL AND SOCIODEMOGRAPHIC CHARACTERISTICS IN FIRST-EPISODE PSYCHOSIS PATIENTS IN A RURAL REGION OF LATVIA
}

\author{
Liene Bērze ${ }^{1,2, \#}$, Karīna Bezina ${ }^{1}$, Konstantīns Pavlovs ${ }^{1}$, Sarmīte Ķikuste ${ }^{1}$, \\ Inna Šapele ${ }^{1}$, and Elmārs Rancāns ${ }^{2}$ \\ ${ }^{1}$ Daugavpils Psychoneurological Hospital, Lielā Dārza iela 60/62, Daugavpils, LV-5417, LATVIA \\ 2 Department of Psychiatry and Addiction Medicine, Rīga Stradiṇš University, 2 Tvaika Str., Rīga, LV-1005, LATVIA \\ \# Corresponding author: lieneberze@gmail.com
}

Communicated by Aivars Lejnieks

The first psychosis is a crucial point for further development of mental disorders. Previous evidence has demonstrated that psychotic disorders, including schizophrenia, are associated with a large number of years living with the disability. It is a global aim to improve prognosis of psychotic disorders, especially in rural regions, where mental health care possibly is not so easily accessible for patients. The aim of this study was to investigate clinical and sociodemographic determinants in association with patient and illness related factors to improve knowledge and understanding of first time psychosis patients in a rural region. This is a descriptive, cohortbased study of all consecutive first episode psychosis (F20, F23, ICD 10) patients admitted in the Daugavpils Psychoneurological Hospital (DPNH) between January 2016 and December 2017. Of the 94 first-time patients hospitalised in DPNH with symptoms of psychosis, 69 met the inclusion criteria. Our results showed that median age of patients was 33 years (IQR 27.5-42.0), median duration of untreated illness (DUI) was 30 months (IQR 11.0-60.0), and median duration of untreated psychosis (DUP) was 8 weeks (IQR 4.0-48.0). The results showed that $55.1 \%$ of first psychosis patients had not seen any health care specialist before being admitted to the psychiatric hospital. We found statistically significant differences between some sociodemographic aspects in DUI/DUP. Patients who lived with relatives had the longest DUI - 36 months, compared with 12 months for those who had established their own family. Unemployed patients had longer DUI 36 months, compared with 12 months for employed patients. Similar findings were shown for associations with DUP. To our knowledge this study adds several important findings that help to better understand first psychosis patients.

Key words: psychotic disorders, duration of untreated psychosis, duration of untreated illness, schizophrenia, first episode psychosis.

\section{INTRODUCTION}

Improvement in psychiatric treatment is one of the landmarks of the twenty-first century as it is stated in the Strategy to Improve Mental Health Care in Latvia 2019-2020 (Anonymous, 2018b): psychiatry is one of three priorities in health care in Latvia in 2019. Because of the specific character of the course of the illness, schizophrenia often remains untreated for a long time before it is recognised and treated (Bertelsen et al., 2008), which has a strong effect on the affected individuals and on society, including long-term disability, unemployment, and reduced life expectancy (Owen et al., 2016; Whiteford et al., 2016). Statistically schizophrenia is known as one of the mental disorders with the highest number of years living with disability (Wittchen et al., 2011; Olesen et al., 2012). Psychosis starts in late adolescence to early adulthood, when it is considered as an early stage of schizophrenia, and is classically viewed as a critical point (Birchwood et al., 1998). Its management not only requires to determine the long-term outcomes, but also consideration of the possibility of realising secondary prevention in psychiatry (Fusar-Poli et al., 2017).

Among all registered patients with mental and behaviour disorders in Latvia in 2017, 22.0\% were registered with diagnoses F20-F29 (Anonymous, 2018c). The Centre for Dis- 
ease Prevention and Control of Latvia in their annual statistic report indicated that every year 365 new cases of schizophrenia-spectrum disorders are registered (persons who went to a health-care specialist in the territory of Latvia and were diagnosed with F20-F29 diagnosis accordingly to ICD-10 (Anonymous, 1992) at the end of visit. This is the fourth most common diagnosis code after organic, including symptomatic, mental disorders (2515 new cases per year), neurotic, stress related and somatoform disorders spectrum disorders (1091 new cases per year), and mood (affective) disorders (732 new cases per year) (Anonymous, 2018c).

In psychotic disorders including schizophrenia, for clinical benefit, it is important to explore modifiable factors such as duration of untreated psychosis, and duration of untreated illness (Marshall and Rathbone, 2011; Murru and Carpiniello, 2018). There is evidence of the influence of psychosocial factors, for example social support (Norman et al., 2018; Novick et al., 2012), and pathways to seeking help in mental health care, which can dramatically affect treatment delay (Temmingh and Oosthuizen, 2008; Bhui et al., 2014). A Danish population study found that demographic factors, such as female gender, higher age, and living in peripheral areas, are associated with prolonged DUP (Hastrup et al., 2018).

Because of the existing significant barriers to access to mental health-care, people living in regional areas diagnosed with mental illness are the most vulnerable (Byrne et al., 2017). Young people in rural areas experience greater difficulties with stress and coping mechanisms, when compared to urban areas (Boyd et al., 2006). This can be explained with longer distance to mental health care centres, social isolation, lower socioeconomic status and higher stigmatisation towards mental illnesses (Lihong et al., 2012).

Mental health care in Latvia, especially emergency psychiatry, which offers psychiatric care for acute psychosis, is organised strictly on catchment area basis, which makes the Daugavpils Psychoneurological Hospital (DPNH) the only institution providing emergency psychiatry in a catchment area of approximately 273375 inhabitants, and consisting of 19 municipalities (city and rural). This region of Latvia is known as Latgale, which covers $22.53 \%$ of the territory of Latvia, and in 2016 it contained $13.9 \%$ of the Latvian population (Anonymous, 2018a). Based on the OECD criteria (Anonymous, 2011), a rural region is classified as having a density of inhabitants less than 150 people per square kilometre. Thus, the majority of municipalities of Latgale are rural, with an overall average population density of 19 inhabitants per square kilometre (Anonymous, 2018a). However, the region includes two governmental level cities: Daugavpils and Rēzekne.

The aims of our study were to explore (1) clinical and sociodemographic patterns in first-episode patients living in a rural region in Latvia, (2) pathways taken to obtain mental health-care during first-episode psychosis, and (3) associations between clinical and sociodemographic determinants in first-episode psychosis. Our hypothesis was that clinical patterns, including duration of untreated illness and duration of untreated psychosis, are associated with social and also demographic characteristics.

To our knowledge there is no study describing psychotic disorders in a rural region of Latvia. In scientific literature less is known about the specifics in psychotic disorders in rural regions. Yet, this remains one of the most challenging environments for mental health care. Therefore, our study is important for obtaining background information that can aid making decisions on the implementation of more effective strategies in treating patients with first psychosis in rural settings.

\section{MATERIALS AND METHODS}

The current study design is descriptive cross-sectional and included all consecutive patients with first episode of psychosis (FEP) admitted in DPNH.

The recruitment time period was between 1 January 2016 and 31 December 2017. For the first assessment we included all consecutive patients presenting psychotic symptoms for the first time in their lifetime in DPNH. The first clinical evaluation and diagnosis were made by certified psychiatrists working in the DPNH emergency room. The diagnosis was confirmed during the initial clinical interview; the first-episode psychosis was defined as an acute psychiatric illness, which fulfilled criteria of F20 or F23 described in the International Classification of Disease 10th revision (Anonymous, 1992).

All assessments and interviews were performed by researchers, psychiatrists and in case of a complicated diagnostic process, consent was reached with the supervisor, a certificated psychiatrist with experience in the field of more than 30 years. Data was collected by interview from each patient on demographic factors (e.g., age, gender), social factors (relationship status, children, employment status, living conditions, education in years), help-seeking behaviour (appointments before admission in psychiatric hospital, initiator for seeking help, and the way how patients were brought to the hospital), and clinical symptomology, including duration of untreated illness (DUI) and duration of untreated psychosis (DUP).

Inclusion criteria were as follows: 1) age 18-65 years at the time of interview; 2) diagnosis of F20 or F23 based on ICD-10;3) clinically stable for participation in the clinical interview; 4) first psychosis episode in their lifetime; and 5) obtained written consent of enrolment in study. Exclusion criteria were as follows: 1) organic aetiology of the presenting psychotic symptoms, e.g., brain/head injuries; 2) exogenous aetiology of presenting psychotic symptoms, including substance abuse induced psychosis; 3 ) comorbidity with intellectual disabilities (IQ $<70$ ), based on previous medical history; 4) use of antipsychotic medication for more than four weeks; and 5) affective psychosis (F30-F39). 
From all consecutive 94 patients with non-affective psychotic symptoms, 69 patients met the inclusion criteria. Twenty-five were excluded for the following reasons: in eight patients the psychosis was caused by an organic pathology, in seven patients the psychosis was induced by substance intoxication, for four patients it was not the first psychotic episode and six patients refused to participate in the study.

All included patients were interviewed two times: within five days of the admission $\left(1^{\text {st }}\right.$ interview) and within three days before discharge from the hospital ( $2^{\text {nd }}$ interview). From 69 patients, both interviews were completed by 56 participants. Ten patients were discharged before they were reached for the second interview, and three patients refused to participate in the second interview. All patients who were not able to participate in the second interview had given informed consent for the use of data from the first interview.

The interviews were constructed by the authors using a semi-structured clinical interview concept. Both interviews were conducted only as face-to-face clinical evaluations, which took 40 to 60 minutes and were conducted only by researchers.

The $1^{\text {st }}$ interview contained three structured blocks. The first block consisted of sociodemographic characteristics. We also included self-reported information about suicide attempts during the patient lifetime and psychotic illnesses in the family history. The provided information was checked by closest family members or others close to the patients. Additional information was derived from medical files, including clinical records from the attending psychiatrist and used for crosschecking the information given by the patient.

The second block was aimed to explore help-seeking behaviour. This block was based on a German study (SchultzeLutter et al., 2015). Information was collected on ways how patients were brought to the hospital: 1) help-seeking initiator (patient him-/herself, family members, friend/colleagues, medical workers or other); 2) first contact with healthcare practitioners before admission to psychiatric emergency room (general practitioner, psychiatrist, other, none); 3) way how the patient was transported to the psychiatric emergency room (by him-/herself, by family members, by ambulance, by ambulance with police escort).

The third block included clinical assessment with the Scale for Assessment of Positive Symptoms (SAPS) (Andreasen, 1984) and Scale for Assessment of Negative Symptoms (SANS) (Andreasen, 1983). SAPS is a widely used assessment scale, which includes four main domains of psychotic positive symptoms (schizophrenia spectrum): hallucinations, delusions, bizarre behaviour and positive formal thought disorder. SANS is a widely used assessment scale, which includes five main domains of psychotic negative symptoms (schizophrenia spectrum): affective flattening or blunting, alogia, avoliation-apathy, anhedonia-asociality and attention. SAPS includes 30 symptoms to be evaluated separately, and four global symptoms - one for each do- main, and SANS includes 19 symptoms, and five global symptoms. Each symptom and global symptom were evaluated with a score 0 (none) to 5 (severe). For SAPS and SANS we used the total score across all domains (including global symptoms) for better comparison between these variables at admission and at discharge (Andreasen et al., 1995).

Determination of duration of untreated psychosis (DUP) was based on clinical judgement during the interview and collected data from closest family members. We used a definition often used in describing first psychosis episodes in Denmark (Malla et al., 2002). DUP was defined as the time period from the onset of psychotic symptoms (a score of 3 and higher on SAPS scale or SANS scale global symptoms evaluation) contiguous with presenting episode to the time of adequate treatment of psychotics.

For DUI we used the following definition: the time from the first unspecific symptoms related to psychosis to the time of adequate treatment of psychosis; there should be no return to a previous stable level of functioning after manifestation of psychotic symptoms (Pelayo-Terán et al., 2018). To obtain information about first psychiatric symptoms we asked the patient, their closest others, and searched in medical records for all symptoms indicating behavioural change, such as anxiety, depression, suicidal ideation, and social withdrawal, as these symptom clusters have previously been described in other studies on first episode psychosis (Malla et al., 2006).

As all patients in this study were admitted in the psychiatric hospital because of psychosis, the admission day was considered as the starting point for adequate treatment — as previously used in literature (Schultze-Lutter et al., 2015).

Additionally, we collected information from medical records about bed day count in the psychiatric hospital and used antipsychotic medications.

Pharmacological treatment in the study sample was coded according to the Anatomical Therapeutic Chemical (ATC) classification index. In this study we evaluated only antipsychotic medication (ACT code N05A, excluding Lithium) used in psychosis treatment, as recommended for treatment in most of the psychosis guidelines in Europe (Anonymous, 2014) and Latvia (Terauds et al., 2014). We collected data only about medication prescribed at the time of discharge for two main reasons: 1) most often the medication at that point was used for more than 14 days and could be considered as effective (Tērauds et al., 2014) and 2) this study was not designed to evaluate specific antipsychotics effects on patients' clinical determinants. We assessed prescribed antipsychotics only for general descriptive purposes.

The data was analysed using SPSS version 22.0. The descriptive statistics included frequencies for categorical variables (shown in absolute numbers and percentages) and the Kolmogorov-Smirnov test for normality. For normally dis- 
tributed variables we applied means and standard deviations, for nonparametric numeric data - medians and interquartile ranges. Additionally, we explored Cohens $d$ and effect size for changes in positive and negative symptomology at the time of admission and discharge. For comparison between categorical variables we used the Pearson ChiSquare test or Fisher's Exact test, with Phi for estimation of effect size (weak effect: Phi < 0.3, medium: 0.3-0.5, large: $>0.5$ ). We used the Mann-Whitney test U test and Kruskal-Wallis test with $\mathrm{r}$ as effect size, to examine differences between gender groups, sociodemographic variables and help seeking variables, and DUI/DUP. For describing relationships, we used two-tailed Spearman's correlation coefficient analysis $\left(r_{s}\right)$. The level of significance for all statistical analyses tasks was set at 0.05 .

The study was approved by the Ethics Committee of Rīga Stradiňš University (RSU).

\section{RESULTS}

From 69 included patients, 36 were male (52.2\%); the median age of the cohort was 33.0 years (IQR 27.5-42.0). There were statistically significant differences between genders - women tended to be older, with median age 35.0 years (IQR 32.0-46.5), than men, who had median age 29.0 years (IQR 26.0-37.0), Mann Whitney U test, $p=0.011$ (effect size 0.31 ). Other descriptive statistics about sociodemographic background information are displayed in Table 1.

Among gender differences tested with the Pearson ChiSquare test, women living significantly more often with their spouses (63.6\% of cases), while men had established their own family only in $16.7 \%$ of cases; $69.4 \%$ of men lived with their relatives and only $27.3 \%$ of women lived with their relatives, $p<0.001(\mathrm{Phi}=0.48)$. There were also significant differences in relationship status: $45.5 \%$ of female patients were married and $18.2 \%$ had a partnership, while for male patients the results were respectively $8.3 \%$ and $8.3 \%, p<0.001$ (Phi $=0.49$ ). Significant differences were found between genders on having children: $81.8 \%$ of women had children, while only $18.2 \%$ of men had children, $p<0.001$.

Help-seeking behaviour is displayed in Table 2.

The median DUI was 30 months (IQR 11.0-60.0), and the median DUP was 8.0 weeks (IQR 4.0-48.00); there were no significant differences between genders in our sample in DUI/DUP.

Nonparametric tests showed significant differences between sociodemographic aspects in DUI/DUP. We found that patients who lived with relatives had the longest DUI - 36 months (IQR 24.0-60.0); for those who lived alone DUI was 30.0 months (IQR 12.0-61.5) and the shortest DUI was for those who had established their own family - 12 months (IQR 4.0-36.0), Kruskal-Wallis test, $p=0.022$ ( $\mathrm{r}=$ 0.33). Significant differences were also found for DUP among living conditions. For patients living with family
Table 1

SOCIODEMOGRAPHIC BACKGROUND INFORMATION ABOUT FIRST PSYCHOSIS EPISODE SAMPLE

\begin{tabular}{|c|c|c|c|}
\hline Characteristic & $\mathrm{n}$ & $\%$ & $p$-value \\
\hline All & 69 & & \\
\hline Male & 36 & $52.2 \%$ & 0.81 \\
\hline $\begin{array}{l}\text { Years of education, including } \\
\text { university Me (IQR) }\end{array}$ & 69 & $\begin{array}{c}12.0 \\
(9.0-15.0)\end{array}$ & n.a. \\
\hline $\begin{array}{l}\text { Marital status } \\
\text { Married/Partnerships } \\
\text { Single/separated }\end{array}$ & $\begin{array}{l}27 \\
42\end{array}$ & $\begin{array}{l}39.1 \% \\
60.9 \%\end{array}$ & 0.09 \\
\hline $\begin{array}{l}\text { Living conditions } \\
\text { Alone } \\
\text { With spouse } \\
\text { With relatives }\end{array}$ & $\begin{array}{c}8 \\
27 \\
34\end{array}$ & $\begin{array}{l}11.6 \% \\
49.3 \% \\
39.1 \%\end{array}$ & $<0.01$ \\
\hline $\begin{array}{l}\text { Have children } \\
\text { Do not have children }\end{array}$ & $\begin{array}{l}35 \\
34\end{array}$ & $\begin{array}{l}50.7 \% \\
49.3 \%\end{array}$ & 0.99 \\
\hline $\begin{array}{l}\text { Work situation } \\
\text { Employed } \\
\text { Unemployed }\end{array}$ & $\begin{array}{l}24 \\
45\end{array}$ & $\begin{array}{l}34.8 \% \\
65.2 \%\end{array}$ & 0.01 \\
\hline Psychiatric illnesses in family & 18 & $26.1 \%$ & n.a. \\
\hline Suicide attempts in lifetime & 8 & $11.6 \%$ & n.a. \\
\hline
\end{tabular}

Table 2

HELP SEEKING BEHAVIOUR BECAUSE OF COMPLAINTS OF PSYCHOTIC SYMPTOMS

\begin{tabular}{l|c|c}
\hline & $\mathrm{n}$ & $\%$ \\
\hline Help seeking initiator & & \\
Patient him/herself & 8 & $11.6 \%$ \\
Family members & 53 & $76.8 \%$ \\
Medical workers & 7 & $10.1 \%$ \\
Other & 1 & $1.4 \%$
\end{tabular}

First contact with health care practitioners before psychiatric ER

$\begin{array}{lcc}\text { General practitioner } & 3 & 4.3 \% \\ \text { Psychiatrist } & 16 & 23.2 \% \\ \text { None } & 38 & 55.1 \% \\ \text { Other } & 12 & 17.4 \%\end{array}$

Other

$17.4 \%$

Way how patient was brought to psychiatric ER

$\begin{array}{lll}\text { Came by themselves } & 6 & 8.7 \%\end{array}$

Brought by family members $\quad 21 \quad 30.4 \%$

$\begin{array}{ll}\text { Brought by ambulance } & 23 \\ \text { Brought by ambulance } & 33.3 \%\end{array}$

Brought by ambulance with police escort $\quad 19 \quad 27.5 \%$

Psychiatric ER, Psychiatric Emergency room

members DUP was 24.00 weeks (IQR 4.0-96.0), living with their own family 5.0 weeks (IQR 2.0-16.0), and for those living alone DUP was 4.0 weeks (IQR 2.0-17.0); Kruskal-Wallis test, $p=0.007(\mathrm{r}=0.38)$. Accordingly, for patients in a relationship of married, the DUI was shorter 12 months (IQR 4.0-36.0), compared with DUI of 36 months (21.0-60.0) for single patients; Mann-Whitney U test, $p=0.017(\mathrm{r}=0.28)$. A similar pattern was found for DUP: for single patients DUP was 16 weeks (IQR 4.0-48.0), for those in a partnership the median DUP was 
five weeks (IQR 2.0-16.0), Mann-Whitney U test, $\mathrm{p}=$ $0,048(r=0.24)$.

We found significant differences in employment status: unemployed patients had a longer DUI - 36 months (IQR 18.0-60.0), when compared to employed patients - 12.0 months (IQR 3.25-36.0); Mann-Whitney U test, $p=0.016$ $(\mathrm{r}=0.29)$. Significant differences were also found between longer DUP and employment status, respectively for employed patients the DUP was four weeks (IQR 2.0-16.0), for unemployed 16 weeks (IQR 4.0-48.0); Mann Whitney $\mathrm{U}$ test, $p=0.016(\mathrm{r}=0.31)$.

We observed a significantly shorter DUP, with median of two weeks (IQR 1.75-12.00), in cases when the patient was the initiator for seeking help. DUP was also noticeably shorter when the initiators for seeking specialist help were medical workers. The DUP in that case had a median of four weeks (IQR 1.75-9.00), but when initiators for helpseeking were relatives, the median DUP was 16 weeks (IQR 4.0-48.0); Kruskal Wallis test, $p=0.018$ ( $\mathrm{r}=0.36$ ). We did not find any other significant associations between helpseeking patterns and DUI in patients with first episode of psychosis.

Results of the assessment of clinical symptomatology for the whole cohort were as follows: median SAPS score during the 1st interview was 67.0 (IQR 53.0-74.5), median SANS was 62.0 (IQR 39.5-74.5), upon discharge the median SAPS score was 20.36 (IQR 20.0-40.0), median SANS was 26.19 (IQR 13.25-54.75).

For better evaluation of active symptomatology and its clinical response to treatment we measured the Cohnens $d$ coefficient and associated effect size. We found that positive symptoms during treatment were changed with effect of intervention $d=1.80, \mathrm{ES}_{r}=0.67$, and also negative symptoms changed with effect of intervention $d=0.87, \mathrm{ES}_{r}=$ 0.40 .

The Mann Whitney U test showed differences between genders in clinical symptomology: male patients had more severe positive symptoms $(p=0.02)$, as well as negative symptoms $(p<0.001)$ at the time of admission, and more severe positive symptoms $(p=0.003)$ and negative symptoms $(p=0.001)$ at the time of discharge, when compared to female patients.

The median time spent in hospital for the cohort was 28 days (IQR 18.0-41.0); there were no significant differences between genders.

In this sample, only $6(10.1 \%)$ patients had used antipsychotic medication before admission to the hospital; none of them exceeded the four week limit.

At the time of discharge $86.9 \%(n=60)$ of patients had a prescription for one atypical antipsychotic medication and $13.0 \%(n=9)$ had a combination of two antipsychotics. From all prescribed antipsychotics the most often used were Risperidone $36.2 \%(n=25)$, Olanzapine $21.7 \%(n=15)$,
Table 3

CORRELATIONS BETWEEN DUI/DUP AND CLINICAL VARIABLES

\begin{tabular}{l|c|c|c|c}
\hline \multicolumn{1}{c|}{ Variable } & \multicolumn{2}{c|}{$\begin{array}{c}\text { DUP } \\
\text { (weeks) }\end{array}$} & \multicolumn{2}{c}{$\begin{array}{c}\text { DUI } \\
\text { (months) }\end{array}$} \\
\cline { 2 - 5 } & $r_{s}$ & $p$ & $r_{s}$ & $p$ \\
\hline $\begin{array}{l}\text { Time spent in hospital } \\
\text { (bed days) }\end{array}$ & $0.258^{*}$ & 0.043 & $0.282 *$ & 0.020 \\
SAPS total score at admission & 0.140 & 0.273 & 0.110 & 0.368 \\
SANS total score at admission & $0.319 *$ & 0.011 & 0.089 & 0.468 \\
SAPS total score at discharge & $0.366^{* *}$ & 0.009 & 0.141 & 0.299 \\
SANS total score at discharge & $0.422^{*}$ & 0.002 & 0.110 & .420
\end{tabular}

Spearmen rank correlation

*Correlation is significant at the 0.05 level (2-tailed)

** Correlation is significant at the 0.01 level (2-tailed)

DUI, duration of untreated illness

DUP, duration of untreated psychosis

Haloperidol 11.6\% ( $\mathrm{n}=8)$, Aripiprazole 10.1\% ( $\mathrm{n}=7)$, Amisulpride 5.8\% ( $n=4)$ and Quetiapine 4.3\% (n=3), and $10.0 \%$ of patients received another antipsychotic or a combination of antipsychotics. In this study we did not find any significant patterns between prescribed antipsychotics and sociodemographic characteristics, clinical symptoms or DUI/DUP.

The Spearmen rank correlation coefficients for relationships between DUI/DUP and all other numerical variables are displayed in Table 3.

\section{DISCUSSION}

We explored clinical and sociodemographic characteristics in patients with non-affective first-episode psychosis in a rural region of Latvia. Our results are based on a sample of patients who are highly representative of patients with first-time psychosis in this catchment area. There was no competing public or private hospital for patients with firstepisode psychosis (FEP) in the catchment area, and access to mental health care is universal and funded from public resources, which allows DPNH to form a representative sample of FEP in the rural region. During the two-year period, we were able to detect 69 true non-affective first-time psychosis in the psychiatric emergency room of DPNH. The catchment area is home to 273375 inhabitants, which is close to the incidence statistic described in literature: psychosis incidence in rural regions of France in 2014 was 17.2 per 100000 (Szöke et al., 2014) and in Canada the treated yearly incidence of FEP was 14.6/100 000 (Malla et al., 2006). Higher incidence was found in England in a conduced meta-analysis research work, where results showed that the pooled incidence for psychotic disorder was 31.7 per 100000 person years (Kirkbride et al., 2012).

Our sample contained $52.2 \%$ male patients and we did not find significant differences in the sample by gender. This finding differs from other studies that showed that in non- 
affective psychosis male patients are represented slightly more (Kvig et al., 2017), (Szöke et al., 2014; Malla et al., 2004), and there is a reported odds ratio of 2.37 for nonaffective psychosis patients being male (Golay et al., 2016).

In our sample the median age was 33.0 years, making our patients older that in other studies: average age 19.9 years (Kvig et al., 2017), 22.1 years (Cratsley et al., 2008), 27.8 years (Marshall and Rathbone, 2011), and 24.2 years (Malla et al., 2002). Compared to a study in a rural region of Japan, the patient mean age was similar to ours, as the first contact with psychiatric services was at the age of 30.1 years. In a previous study conducted in Latvia on the first time of onset of psychosis in urban region, the mean age was 35.7 (SD 12.3) years for women and 30.0 (SD 10.8) for men, which is comparable with our findings (Rusaka and Rancans, 2014). There are several explanations for the different results. Firstly, because of nonparametric data, we used medians to describe patient age, which result in higher values than for mean age. Secondly, the study was carried out in a rural environment, where delayed treatment might be expected. Location in a rural environment can be divided into extrinsic factors, for example, lack of transportation, lack of financial resources, social isolation, stigmatisation against mental health, as well as intrinsic factors, such as more insidious course of illness (Lihong et al., 2012).

In our sample, men were younger than women. At the time of admission with psychotic symptoms, the median age for men was 29.0 years, and for women -35.0 years. Earlier hospitalisation of men had been described to be associated with more aggressive behaviour, society attitudes against men and being afraid from physical violence, and the association of male gender with illegal substance use (Køster et al., 2008; O’Donoghue et al., 2016). Our results confirm this, with significantly more severe positive symptoms at admission and at discharge in men compared to women. We stress that the negative symptoms were more severe for men, whereby at the first contact with a mental health-care specialist men presented with more severe clinical symptoms.

An important finding in our study was the social determinants of first-time psychosis patients. Even before the first contact with a mental health-care professional, $65.2 \%$ of participants were already unemployed and $39.1 \%$ of them were living with relatives, not being able to establish their own family, even though the median length of education was 12 years. Another relevant social determinant found in this study was that $60.9 \%$ of patients were single. Similarly, in Canada, $73.0 \%$ of patients in a first episode sample were unmarried (Malla et al., 2002). We additionally found that female patients were significantly more involved in partnerships and had children more often than male patients. This is linked with the women's role in the cultural environment, Latgale is a traditionally oriented region with expectation for women to have families and children, even when there are signs of disturbed wellbeing.
We speculate that in rural regions psychosis may start later. Therefore, the education level in our sample is high enough, but after the onset of psychiatric symptoms there is accumulative social and functional disadaptation. This assumption is supported by the fact that in our sample the median DUI was 30 months, which represents a 2.5-year period living with psychiatric symptoms without treatment. We found that persons living with relatives had a longer DUI (median 36 months), which could be explained by the ability of close relatives to tolerate and "get used" to odd behaviour or mental health struggles of a family member. In literature, the reasons mentioned that explain why families do not seek help when problems become apparent may be associated with other variables, such as explanatory models of illness, stigma, and socio-economic or educational background (Singh and Grange, 2006).

The calculated DUI of 36 months is comparable with that indicated in literature: from published epidemiologic studies it is known that DUI in schizophrenia spectrum psychosis varies from 36 months to even eight years (Dell'Osso et al., 2013). In a study of DUI in FEP, DUI had a median of 154.9 weeks or, when converting the median DUI to months, 35 months (Malla et al., 2006).

The median of 8 weeks for DUP in our sample is similar to that estimated in other studies, where DUP varied from 4 weeks to 68 weeks (Anderson et al., 2010). Regarding our study it is worth highlighting that all patients presenting with first psychosis episode were admitted in an acute psychiatric ward, which clinically indicates more severe and acute state without the possibility to manage the psychotic symptoms in an out-patient care settings. This finding is in concordance with observations from other authors on psychosis in acute psychiatric wards (Cratsley et al., 2008; Bhui et al., 2014; Sharifi et al., 2009).

Regarding clinical symptoms, we found that a longer DUP was associated with more severe positive symptoms at discharge. In a Canadian study, a longer DUP was associated with more severe positive symptoms after a one year follow up period (Malla et al., 2002). In this study we found a moderately-strong correlation between a DUP and severity of negative symptoms at admission and at discharge, which agrees with previous research showing that longer DUP was associated with reduction of negative symptoms of schizophrenia spectrum disorders (Chang et al., 2013). To emphasise this finding, we found that during treatment in hospital the positive symptoms changed with a large effect size, while negative symptoms changed with only with a small effect size; thus, clinical remission mainly was achieved by reducing positive symptoms, but negative symptoms remained difficult to manage.

In our study sample the prescribed antipsychotic medication mirrored prescription choices given in national guidelines, with the first two choices being novel antipsychotics such as Risperidone (36.2\%) and Olanzapine (21.7\%), leaving the only used typical antipsychotic Haloperidol (11.6\%) in third place, followed by other novel antipsychotics. Pooled 
together $86.9 \%$ patients were prescribed novel antipsychotics in monotherapy and $13.0 \%$ were prescribed a combination of typical with atypical or only typical antipsychotic, which is in-line with guidelines and other studies in FEP patient populations (Brostedt et al., 2017; Malla et al., 2002; Pelayo-Terán et al., 2018). We did not find any association between medications and other determinants characterising FEP in this sample.

To our knowledge this is the first study in Latvia to examine help-seeking ways to mental health care in first episode psychosis within rural settings. It was disappointing to find that $55.1 \%$ of patients with first psychosis had never seen any health-care specialist before and that only $23.2 \%$ had seen a psychiatrist, making this the most often seen specialist before admission in hospital. Only $4.3 \%$ had seen a general practitioner. This is in contrast with a study showing that GPs have a role as gatekeeper to access to a mental health-care specialist (Anderson et al., 2010). These findings can be explained by the mental health-care organisation system in Latvia, where the psychiatrist is a direct accessibility specialist, fully paid by the government, and no referral from a GP is needed. In one study where geographical differences were examined (Kvig et al., 2017), direct help-seeking for a mental health-care professional was dependent on location: urban or rural region. In urban areas where there are wider social networks, it can be less likely that the patient was first contacts emergency clinics (Bhui et al., 2014), as opposed to regional facilities.

Regarding ways how patients were brought to the psychiatric emergency room, we found that $30.4 \%$ were brought by family members, $33.3 \%$ were brought by ambulance, $27.5 \%$ by ambulance escorted by police and only $8.7 \%$ came by themselves. This finding allows us to speculate that in rural regions of Latvia the gatekeepers for mental health care are medical workers in ambulances. Regarding the initiator of help-seeking due to psychotic symptoms, for $76.8 \%$ of patients family members made the decision to see a mental health specialist, which is very similar to that mentioned in another first episode rural study (Lihong et al., 2012). This is also in concordance with the already established role of others in help-seeking, which becomes more prominent with increasing severity of symptoms(Schultze-Lutter et al., 2015), and, as we mentioned, our sample contained acute psychosis patients. This allows us to stress the importance of family member awareness and knowledge of mental health needs.

It is important to highlight that in our sample $26.1 \%$ had a psychiatric illness in first degree relatives. There is evidence that patients with first-degree relatives with psychiatric illness have increased risk of subsequent diagnosis of schizophrenia or schizoaffective disorder with an OR of 1.9 [95\% CI 1.1 to 3.0] (Björkenstam et al., 2013). There is a need to put effort in educating families and patients, not only for patients with FEP to expand their social networks and reduce stigmatisation, but also considering them as future parents.
Strengths and limitations. The strength of this study is that we were able to obtain a representative number of patients with first-time psychosis in the relevant rural region, which the main limitation is that we cannot exclude the possibility of patients voluntarily bringing themselves to other psychiatric hospitals in different regions. Another strength was that we examined a sample in which the majority of firsttime patients were drug naïve, which gave us reliable clinical findings in duration of untreated psychosis and duration of untreated illness.

However, we acknowledge that there are several limitations. First, methodologically, the applied criteria for first episode psychosis in this study was not based on recent scales developed for the purpose of detecting and indicating a psychotic episode. We used a more conservative method with SAPS and ICD-10 diagnostic criteria, which can cause bias differences due to different inclusion criteria, sampling and clinical evaluation. Second, we determined the duration of untreated illness and untreated psychosis by definition based on retrospective observations of patients' symptoms by themselves and by their relatives, which may lead to recall bias and may also be biased by significant other knowledge of the patient (Hastrup et al., 2018). In this study we tried to minimise this phenomenon by cross-checking the information with several closest family members, and also checked all available medical documentation in DPNH.

To conclude, our study revealed several important findings that can aid to better understand FEP patient demographic, social and clinical portraits in rural regions. We found that patients with first-episode psychosis during their first contact with a mental health-care specialist were mostly unemployed, living with their relatives, were single, and did not seek any psychiatric help before the first contact with a mental health-care specialist in psychiatric emergency rooms, and these characteristics were partly associated with a longer DUI/DUP. We hope that these finding will help to put more effort in educating society, social institutions, and also healthcare specialists for more effective detection of psychotic symptoms, and that these findings will motivate the development of more tailored and contemporary treatment for FEP, such as early intervention. Clearly there is need for multiprofessional team work to ensure not only clinical remission, but also functional (personal and professional) recovery with reintegration in society.

\section{ACKNOWLEDGEMENTS}

We would like to express our gratitude to the administration of DPNH: S. Kikuste, I. Sapele, J. Lazovika; and chairs of acute wards: I. Samule, J. Zīle, N. Kurakina, T. Abrazovica and $V$. Bodins, for supporting our initiative and scientific work in the hospital environment.

\section{REFERENCES}

Anderson, K. K., Fuhrer, R., Malla, A. K. (2010). The pathways to mental health care of first-episode psychosis patients: A systematic review. Psychol. Med., 40 (10), 1585-1597. 
Andreasen, N. C., Arndt, S., Miller, D., Flaum, M., Nopoulos, P. (1995). Correlational studies of the Scale for the Assessment of Negative Symptoms and the Scale for the Assessment of Positive Symptoms: An overview and update. Psychopathology, 28 (1), 7-17.

Anonymous (1992). International Classification of Diseases. $10^{\text {th }}$ revision (ICD-10) Classifications of Mental and Behavioural Disorder: Clinical Descriptions and Diagnostic Guidelines. World Health Organisation, Geneva.

Anonymous (2011). OECD regional typology, Directorate for Public Governance and Territorial Development. Available from:

https://www.oecd.org/cfe/regional-policy/OECD_regional_typology_ Nov2012.pdf (accessed 10.06.2019).

Anonymous (2014). National Institute for Health and Care Excellence. Psychosis and schizophrenia in adults: prevention and management (NICE Guideline 178). Available from:

https://www.nice.org.uk/guidance/CG178 (accessed 15.05.2019).

Anonymous (2018a). Population numbers and characteristics of Latvia. Central Statistical Bureau of Latvia. Available from:

http://data1.csb.gov.lv/pxweb/en/iedz/iedz__iedzskaits__ikgad/ISG040.p $\mathrm{x} /$ table/tableViewLayout1/ (accessed 10.06.2019).

Anonymous (2018b). Psihiskās veselības aprūpes pieejamības uzlabošanas plāns 2019.-2020.gadam [Plan for improvement for mental health availability 2019-2020]. Ministry of Health of the Republic of Latvia (in Latvian). Available from: http://tap.mk.gov.lv/lv/mk/tap/?pid=40470678 (accessed 10.06.2019)

Anonymous (2018c). The Centre for Disease Prevention and Control of Latvia, Register of Mental and Behavioural Disorders in Latvia in 2017. Available from:

https://www.spkc.gov.lv/lv/statistika-un-petijumi/statistika/veselibas-apr upes-statistika1 (accessed 15.05.2019).

Bertelsen, M., Jeppesen, P., Petersen, L., Thorup, A., Ohlenschlaeger, J., le Quach, P., Nordentoft, M. (2008). Five-year follow-up of a randomized multicenter trial of intensive early intervention vs standard treatment for patients with a first episode of psychotic illness: the OPUS trial. Arch. Gen. Psychiatry, 65 (7), 762-771.

Bhui, K., Ullrich, S., Coid, J. W. (2014). Which pathways to psychiatric care lead to earlier treatment and a shorter duration of first-episode psychosis? BMC Psychiatry, 14 (1), 72.

Birchwood, M., Todd, P., Jackson, C. (1998). Early intervention in psychosis. The critical period hypothesis. The British Journal of Psychiatry. Supplement, 172 (33), 53-59.

Björkenstam, E., Björkenstam, C., Hjern, A., Reutfors, J., Bodén, R. (2013). A five year diagnostic follow-up of 1840 patients after a first episode non-schizophrenia and non-affective psychosis. Schizophrenia Res., 150 (1), 205-210

Boyd, C. P., Aisbett, D. L., Francis, K., Kelly, M., Newnham, K., Newnham, K. (2006). Issues in rural adolescent mental health in Australia. Rural and Remote Health, 6 (1), 501.

Brostedt, E. M., Msghina, M., Persson, M., Wettermark, B. (2017). Health care use, drug treatment and comorbidity in patients with schizophrenia or non-affective psychosis in Sweden: A cross-sectional study. BMC Psychiatry, 17 (1), 1-11.

Byrne, L., Happell, B., Reid-Searl, K. (2017). Acknowledging rural sisadvantage in mental health: Views of peer workers. Persp. Psychiatr. Care, 53 (4), 259-265.

Chang, W. C., Hui, C. L. M., Tang, J. Y. M., Wong, G. H. Y., Chan, S. K. W., Lee, E. H. M., Chen, E. Y. H. (2013). Impacts of duration of untreated psychosis on cognition and negative symptoms in first-episode schizophrenia: A 3-year prospective follow-up study. Psychol. Med., 43 (9), 1883-1893.

Cratsley, K., Regan, J., Mcallister, V., Simic, M., Aitchison, K. J. (2008). Duration of untreated psychosis, referral route, and age of onset in an early intervention in psychosis service and a local CAMHS. Child and Adolescent Mental Health, 13 (3), 130-133.

Dell'Osso, B., Camuri, G., Benatti, B., Buoli, M., Altamura, A. C. (2013). Differences in latency to first pharmacological treatment (duration of un- treated illness) in anxiety disorders: A study on patients with panic disorder, generalized anxiety disorder and obsessive-compulsive disorder. Early Intervention in Psychiatry, 7 (4), 374-380.

Fusar-Poli, P., McGorry, P. D., Kane, J. M. (2017). Improving outcomes of first-episode psychosis: an overview. World Psychiatry, 16 (3), 251-265.

Golay, P., Alameda, L., Baumann, P., Elowe, J., Progin, P., Polari, A., Conus, P. (2016). Duration of untreated psychosis: Impact of the definition of treatment onset on its predictive value over three years of treatment. $J$. Psychiatr. Res., 77, 15-21.

Hastrup, L. H., Haahr, U. H., Jansen, J. E., Simonsen, E. (2018). Determinants of duration of untreated psychosis among first-episode psychosis patients in Denmark: A nationwide register-based study. Schizophr. Res., 192, 154-158.

Kirkbride, J. B., Errazuriz, A., Croudace, T. J., Morgan, C., Jackson, D., Boydell, J., Jones, P. B. (2012). Incidence of schizophrenia and other psychoses in England, 1950-2009: A systematic review and meta-analyses. PLOS ONE, 7 (3).

Køster, A., Lajer, M., Lindhardt, A., Rosenbaum, B. (2008). Gender differences in first episode psychosis. Soc. Psychiatry and Psychiatric Epidemiol., 43 (12), 940-946.

Kvig, E. I., Brinchmann, B., Moe, C., Nilssen, S., Larsen, T. K., Sørgaard, K. (2017). Geographical accessibility and duration of untreated psychosis: Distance as a determinant of treatment delay. BMC Psychiatry, 17 (1), $1-11$.

Lihong, Q., Shimodera, S., Fujita, H., Morokuma, I., Nishida, A., Kamimura, N., Inoue, S. (2012). Duration of untreated psychosis in a rural/suburban region of Japan. Early Intervention in Psychiatry, 6 (3), 239-246.

Malla, A. K., Norman, R. M. G., Manchanda, R., Ahmed, M. R., Scholten, D., Harricharan, R., Takhar, J. (2002). One year outcome in first episode psychosis: Influence of DUP and other predictors. Schizophrenia Res., 54 (3), 231-242.

Malla, A. K., Norman, R. M. G., McLean, T. S., MacDonald, C., McIntosh, E., Dean-Lashley, F., Ahmed, R. (2004). Determinants of quality of life in first-episode psychosis. Acta Psychiatrica Scand., 109 (1), 46-54.

Malla, A., Norman, R., Schmitz, N., Manchanda, R., Béchard-Evans, L., Takhar, J., Haricharan, R. (2006). Predictors of rate and time to remission in first-episode psychosis: A two-year outcome study. Psychol. Med., 36 (5), 649-658.

Marshall, M., Rathbone, J. (2011). Early intervention for psychosis. Schizophr. Bull., 37 (6), 1111-1114.

Murru, A., Carpiniello, B. (2018). Duration of untreated illness as a key to early intervention in schizophrenia: A review. Neurosci. Lett., 669, 59-67.

Norman, R. M. G., MacDougall, A., Manchanda, R., Harricharan, R. (2018) An examination of components of recovery after five years of treatment in an early intervention program for psychosis. Schizophr. Res., 195 469-474.

Novick, D., Haro, J. M., Hong, J., Brugnoli, R., Lepine, J. P., Bertsch, J., Alvarez, E. (2012). Regional differences in treatment response and three year course of schizophrenia across the world. J. Psychiatr. Res., 46 (7), 856-864.

O’Donoghue, B., Roche, E., Lane, A. (2016). Neighbourhood level social deprivation and the risk of psychotic disorders: A systematic review. Soc. Psychiatry Psychiatric Epidemiol., 51 (7), 941-950.

Olesen, J., Gustavsson, A., Svensson, M., Wittchen, H.-U., Jonsson, B. (2012). The economic cost of brain disorders in Europe. Eur. J. Neurol., 19 (1), 155-162.

Owen, M. J., Sawa, A., Mortensen, P. B. (2016). Schizophrenia. Lancet (London, England), 388 (10039), 86-97.

Pelayo-Terán, J. M., Gajardo-Galán, V., Gómez-Revuelta, M., Ortiz-García de la Foz, V., Ayesa-Arriola, R., Tabarés-Seisdedos, R., Crespo-Facorro, B. (2018). Duration of active psychosis and functional outcomes in first-episode non-affective psychosis. Eur. Psychiatry, 52, 29-37. 
Rusaka, M., Rancans, E. (2014). First-episode acute and transient psychotic disorder in Latvia: A 6-year follow-up study. Nordic J. Psychiatry, 68 (1), 24-29.

Schultze-Lutter, F., Rahman, J., Ruhrmann, S., Michel, C., Schimmelmann, B. G., Maier, W., Klosterkotter, J. (2015). Duration of unspecific prodromal and clinical high risk states, and early help-seeking in first-admission psychosis patients. Soc. Psychiatry Psychiatric Epidemiol., 50 (12), 1831-1841.

Sharifi, V., Kermani-Ranjbar, T., Amini, H., Alaghband-Rad, J., Salesian, N., Seddigh, A. (2009). Duration of untreated psychosis and pathways to care in patients with first-episode psychosis in Iran. Early Intervention in Psychiatry, 3 (2), 131-136.

Šica, K., Pulmanis, T., Taube, M. (2017). Psihiskā veselība Latvijā 2016. gadā [Mental health in Latvia in 2016]. The Centre for Disease Prevention and Control of Latvia. Available from: https://www.spkc.gov.lv/upload/Psihiska_veseliba_faili/tz_pvl_2016_final.pdf (accessed 15.05.2019)

Singh, S. P., Grange, T. (2006). Measuring pathways to care in first-episode psychosis: A systematic review. Schizophrenia Res., 81 (1), 75-82.

Received 6 December 2018

Accepted in the final form 23 April 2019
Szöke, A., Charpeaud, T., Galliot, A. M., Vilain, J., Richard, J. R., Leboyer, M., Schürhoff, F. (2014). Rural-urban variation in incidence of psychosis in France: A prospective epidemiologic study in two contrasted catchment areas. BMC Psychiatry, 14 (1).

Temmingh, H. S., Oosthuizen, P. P. (2008). Pathways to care and treatment delays in first and multi episode psychosis: Findings from a developing country. Soc. Psychiatry Psychiatric Epidemiol., 43 (9), 727-735.

Tērauds, E., Rancāns, E., Andrēzina, R., Kupča, B., Kiece, I., Zārde, I., Bezborodovs, N,. (2014). Latvian Psychiatric Association, Šizofrēnijas diagnostikas un ārstēšanas vadlīnijas [Guidelines for schizophrenia diagnostics and treatment], (in Latvian) Available from: https://www.rsu.lv/sites/default/files/imce/Dokumenti/pnk/ LPA_Sizofrenijas_vadlinijas_2014.pdf (accessed 15.05.2019).

Whiteford, H. A., Ferrari, A. J., Degenhardt, L., Feigin, V., Vos, T. (2016). Global Burden of Mental, Neurological, and Substance Use Disorders: An Analysis from the Global Burden of Disease Study 2010. In: Disease Control Priorities. Third Edition (Volume 4): Mental, Neurological, and Substance Use Disorders. The World Bank, Washington, pp. 29-40.

Wittchen, H. U., Jacobi, F., Rehm, J., Gustavsson, A., Svensson, M., Jönsson, B., Steinhausen, H. C. (2011). The size and burden of mental disorders and other disorders of the brain in Europe 2010. Eur. Neuropsychopharmacol., 21 (9), 655-679.

\section{KLĪNISKIE UN SOCIĀLDEMOGRĀFISKIE RĀDĪTĀJI PIRMĀS EPIZODES PSIHOZES PACIENTIEM LATVIJAS LAUKU REGTIONĀ}

Šizofrēniskā spektra saslimšanas visā pasaulē ir viens no biežākajiem invaliditātes cēloṇiem cilvēkiem darba spējīgā vecumā. Pirmā psihozes epizode tiek uzskatīta par vienu kritiskajiem punktiem tālākā slimības attīstībā. Pētījuma mērkis bija iegūt demogrāfisku un klīnisku informāciju par pirmreizējiem šizofrēniska spektra pacientiem lauku reǵionā, lai radītu izpratni par situāciju kopumā. Pētījuma norises laikā no 01.01.2016. līdz 31.12.2017. tika intervēti visi pirmās psihozes epizodes (SSK-10, F23, F20) pacienti, kas iestājās pirmo reizi dzīvē ārstēšanai Daugavpils Psihoneiroloğiskajā slimnīcā. Iekḷaušanas kritērijiem atbilda 69. Klīniskā intervija sastāvēja no trīs blokiem: sociāldemogrāfiskie rādītāji, palīdzības meklēšanas uzvedība saistībā ar psihotiskiem simptomiem un klīniska simptomātika (Pozitīvo simptomu novērtēšanas skala (SAPS) un Negatīvo simptomu novērtēšanas skala (SANS), neārstēts slimības ilgums (NSI), neārstēts psihozes ilgums (NPI)). Svarīgākie rezultāti: pacientu vecuma mediāna 33.0 gadi (IQR 27.5-42.0), vīrieši bija ticami jaunāki ar mediānas vecumu 29.0 gadi (IQR 26.0-37.0), sievietēm 35.0 (IQR 32.0-46.5). Mediānais NSI bija 30 mēneši (IQR 11.0-60.0), NPI astoṇas nedēḷas (IQR 4.0-48.0). Tika atrastas nozīmīgas atškirīības NSI ietekmei uz sociālajiem rādītājiem: pacienti ar ilgāku NSI dzīvoja kopā ar radiniekiem, bija bez attiecībām un nestrādāja. No visiem pacientiem $55.1 \%$ pirms iestāšanās slimnīcā nebija vērsušies pie veselības aprūpes speciālistiem saistībā ar psihotiskiem simptomiem. Pētījuma rezultāti ḷauj secināt, ka pirmās psihozes epizodes pacienti jau pirmā kontakta laikā ar psihiatriskās palīdzības speciālistu ir bez nodarbinātības, dzīvo ar radiniekiem, nav nodibinājuši attiecības, kā arī lielākajā skaitā gadījumu iepriekš nav vērsušies pēc psihiatriskās palīdzības, un šie rādītāji ir daḷēji saistīi ar ilgāku NSI un NPI. Tas norāda uz nepieciešamību attīstīit efektīvas agrīnas intervences pirmās psihozes pacientu sekundārajā profilaksē un veicināt sabiedrības izglītošanu psihotisko traucējumu gadījumos lauku reǵionos dzīvojošajiem. 